This is a final draft of the published article: J. M. Pearce and Paul J. Harris, "Reducing greenhouse gas emissions by inducing energy conservation and distributed generation from elimination of electric utility customer charges", Energy Policy, 35, pp. 6514-6525, 2007.

\title{
Reducing Greenhouse Gas Emissions by Inducing Energy Conservation and Distributed Generation from Elimination of Electric Utility Customer Charges \\ Joshua M. Pearce ${ }^{1}$ and Paul J. Harris \\ Physics Department, 106 Peirce Science Center, Clarion University of Pennsylvania, Clarion, PA 16214, USA
}

\begin{abstract}
This paper quantifies the increased green house gas emissions and negative effect on energy conservation (or "efficiency penalty") due to electric rate structures that employ an unavoidable customer charge. First the extent of customer charges was determined from a nationwide survey of U.S. electric tariffs. To eliminate the customer charge nationally while maintaining a fixed sum for electric companies for a given amount of electricity, an increase of $7.12 \%$ in the residential electrical rate was found to be necessary. If enacted, this increase in the electric rate would result in a $6.4 \%$ reduction in overall electricity consumption, conserving 73 billion $\mathrm{kW}$-hrs, eliminating 44.3 million metric tons of carbon dioxide, and saving the entire U.S. residential sector over $\$ 8$ billion per year. As shown here, these reductions would come from increased avoidable costs thus leveraging an increased rate of return on investments in energy efficiency, energy conservation behavior, distributed energy generation, and fuel choices. Finally, limitations of this study and analysis are discussed and conclusions are drawn for proposed energy policy changes.
\end{abstract}

Keywords: carbon dioxide, distributed generation, energy conservation, energy efficiency, electricity conservation, green house gas, utility rates

\section{Introduction:}

Global climate destabilization is primarily due to the combustion of fossil fuels for energy and the resultant carbon dioxide $\left(\mathrm{CO}_{2}\right)$ emissions, a potent greenhouse gas (GHG) (IPCC, 2007a). The Intergovernmental Panel on Climate Change warns that unmitigated, climate change in the long term is likely to exceed the capacity of natural, managed and human systems to adapt (2007b). Clearly it is in the public's best interest to have an aggressive mix of strategies that includes mitigation, adaptation, and technological development to subvert serious harms to the global environment, human health and the long-term viability of the economy due to climate change. Even small changes to policies or behaviors that save energy and reduce emissions, in aggregate can have a profound effect on energy use, national energy economics, and the global climate (Pearce and Hanlon, 2007). This paper focuses on the effects of eliminating the electrical utility customer charge to encourage efficient use of electricity.

Currently, based on regulations from the public utility commissions in all 50 U.S. states, the electric utilities may break monthly electrical charges into two parts: 1) the customer charge - a fixed charge (\$/bill), and 2) charge based on actual consumption of electricity ( $\$ / \mathrm{kW}-\mathrm{hrs})$. This charge is the same, independent of electricity consumption. This method of billing has created an incentive to use electricity less efficiently, and thus increase the GHG emissions due to electricity generation. For all electricity

\footnotetext{
${ }^{1}$ Author to whom correspondence should be addressed. Phone:814-393-2713, Fax: 814-393-1630, email: jpearce@ clarion.edu
} 
This is a final draft of the published article: J. M. Pearce and Paul J. Harris, "Reducing greenhouse gas emissions by inducing energy conservation and distributed generation from elimination of electric utility customer charges", Energy Policy, 35, pp. 6514-6525, 2007.

consumers that pay fixed customer charges, the more electricity they use the less per unit energy they pay for it. This paper explores the effect on consumer energy choices and emissions from a rate structure change in which the customer charge is eliminated while maintaining a fixed sum for utility companies for a given amount of electricity consumption.

First this paper reviews the regulations revolving around the customer charge, details the resultant "efficiency penalty" as a function of energy consumption, and then it employs the following methodology to provide a solution. The extent of customer charges in the U.S. is established by surveying utility tariffs in all 50 states. Then the following is determined based on a new proposed national electricity regulations that eliminate all customer charges by folding them into slightly increased rate charges for all consumers : i) quantification of the rate increase (cost per kW-hr) needed to eliminate the customer charge nationally, ii) estimates on green house gas emissions reductions enabled by increased electricity rates, and iii) the effect on rate of return on energy efficiency investments, distributed energy generation economics, and fuel choice. Finally, limitations of this study and analysis will be discussed and conclusions will be drawn for suggested policy changes.

\section{The Customer Charge}

The customer charge is a fixed, recurring (monthly or daily) charge that all customers pay whether or not they use any electricity. Customer charges initially gained acceptability on the grounds that metering and billing costs are not related to usage at all, and were adopted by commissions in part on that basis (Weston, et al., 2000). One variant of the standard customer charge is the "minimum bill", which requires payment of a monthly charge, but with it also comes a specified number of "free" kW-hrs before being billed on a per unit basis. Initially, the customer charges were generally low, although this is changing because there is electric utility pressure to have an increasing portion of residential electric bills come from fixed charges. Electric utilities favor fixed charges like the customer charge because, like many businesses they derive their revenue by charging for their variable services (electricity consumed on a monthly basis) even though many of their costs are fixed and do not vary strongly with the amount of electricity consumed. In addition to the decreased risk by ensuring revenue stability from customer charges, electric utilities support such rate schedules because high customer charges: i) limit the perceived competition and threat to profits from energy efficiency and distributed generation, ii) positions the electric utility well against gas companies and can influence fuel choice among customers in their favor, and iii) can increase profits of affiliated marketers and generators, and (if they do not obtain 100\% distribution customer charges) increase profits of the regulated company under performance-based ratemaking (Marcus and Coyle, 1999).

Public Utilities Commissions (PUCs) regulate electricity providers for the benefit of the public. Although, the fiscal health of the utility is usually a good surrogate for the public benefit it is not always the case because many social benefits, including economic benefits, accrue to society as a whole and not necessarily the utility from various rate structures. Regulators have long resisted disproportionate growth in fixed charges primarily because of their adverse impacts on low-volume users. Now, however, regulators allow considerable customer charges in many states. Increases in customer charges are being 
This is a final draft of the published article: J. M. Pearce and Paul J. Harris, "Reducing greenhouse gas emissions by inducing energy conservation and distributed generation from elimination of electric utility customer charges", Energy Policy, 35, pp. 6514-6525, 2007.

formulated on two additional bases: 1) treating distribution charges as customer charges, and 2) folding additional equipment costs of time of use billing into customer charges.

\subsection{Distribution Charges as Customer Charges}

There has been an expanding array of proposals to increase the customer charge from utilities by including the distribution charges. For example, the Nevada Public Service Commission approved a proposal from the Nevada Power Company and Sierra Power that significantly increased the monthly recurring customer charges to cover all distribution costs (Takahashi, et al., 2005). Similarly, Southern California Edison filed a proposal for a $\$ 17.00 /$ month fixed customer charge for residential consumers arguing that distribution system costs are for the most part fixed and do not vary with load or throughput and therefore should be covered in fixed, recurring charges (2000). The fallacy of this argument is that large portions of the distribution system (even for a summer peaking utility) must be built more expensively to serve neighborhoods of new electric heat customers than customers using gas for space and water heating (Marcus and Coyle, 1999). While distribution costs are not sensitive to usage in the short-term (because the embedded costs of serving a high-volume customer vs. a low volume customer are equivalent), distribution costs are in fact sensitive to usage in the long-term, as growing electricity demand requires costly equipment upgrades (Takahashi, et al., 2005). When distribution costs are split into customer and demand portions (e.g. splitting the distribution system into a minimum usage [customer charge] and above minimum usage portion [per kW-hr charge]), low-use or efficient electricity consumers are charged twice: once on a customer basis, for a portion of the system sized to meet their demands; and again on a demand basis for a portion of the system sized to serve demand beyond what would be needed to serve them (Sterzinger, 1981). Energy efficient electrical consumers are thus overcharged. Sterzinger concluded that the only reasonable remedy for the problem of overcharging was to classify the entire distribution system on a consistent basis, which would be a demand basis, where traditional cost-of-service studies do not support a high customer charge.

\subsection{Time of Use Rates as Customer Charges}

In order to more accurately follow the actual price of electricity, pricing is becoming progressively more time-based, using time-of-use (TOU) rates, critical peak pricing (CPP), and real-time pricing (RTP). All time-based rates other than seasonal rates require meters that register customer electricity consumption based on time-of-day or more frequent billing blocks. Traditional meters for smaller customers such as residential homes and small businesses that were installed several years ago, or even newer remotely readable ones, still tend not to record time-of-day usage (FERC, 2006). The Federal Energy Regulatory Commission (FERC) has suggested that the additional capital and operating cost of replacing or upgrading these meters can be included in separate customer charges, as determined by individual public utility commissions, if customers choose TOU rates (FERC, 2006). The capital investment for the new TOU meters and installation will thereby be again shifted to the energy consumers, effectively increasing their customer charge - or non-avoidable electricity costs. There is considerable evidence that TOU pricing is an environmental benefit because it shifts utilities away from the least efficient (and often most expensive) traditional energy supplies because it provides an economic incentive for energy consumers to modify their energy use to reduce peak demand (Taylor and Schwarz, 1990). Treating 
This is a final draft of the published article: J. M. Pearce and Paul J. Harris, "Reducing greenhouse gas emissions by inducing energy conservation and distributed generation from elimination of electric utility customer charges", Energy Policy, 35, pp. 6514-6525, 2007.

TOU equipment as an additional customer charge, negates some of the environmental benefits of TOU by discouraging electricity conservation as will be shown below.

\section{The Customer Charge "Efficiency Penalty"}

As discussed in section 1, customer charges and other fixed charges are currently being used to subsidize the electricity costs for large consumers at the expense of more energy efficient users in direct opposition to the public's best interest. Because of this rate structure, large institutional users are able to take advantage of the full economic benefits of their energy conservation efforts, while relatively small energy consumers are not. This can be more easily understood by looking at the difference between the avoidable electricity cost and the actual electricity cost for electricity. Figure 1 illustrates this point using the customer charge for Allegheny Power customers in Pennsylvania (\$10.00/month) with its concomitant avoidable rate cost per $\mathrm{kW}-\mathrm{hr}$ of $\$ 0.0626$. As can be seen Figure 1, the disparity between the actual and avoidable cost is substantial until over $400 \mathrm{~kW} / \mathrm{hrs}$ per month is consumed. The percentage of the bill made up by the customer charge can be seen in the inset in Figure 1 as a function of kW-hrs/month.

Examples from small and medium sized users illustrate the small user or "efficiency penalty" of fixed customer charges. For example, for a small user -- a single person living in an apartment that is individually sub-metered, who uses only $1 \mathrm{~kW}$-hr per day primarily to run a refrigerator and some lights is effectively paying 40 cents per $\mathrm{kW}$-hr rather than 6 cents $/ \mathrm{kW}$-hr and $84 \%$ of her bill is derived from the customer charge.

The efficiency penalty can effectively discourage energy efficiency. For example consider a couple using $190 \mathrm{~kW}$-hrs a month, which effectively doubled the electric rate from 6 to 12 cents per kW-hr and has $45 \%$ of their bill go to the unavoidable customer charge. If they decide to try to lower their electric bill and deploy energy efficient appliances, they may drop their electricity use to $100 \mathrm{~kW}$-hrs per month. Then $61.5 \%$ of their bill goes towards the customer charge and they are paying an effective rate of 16 cents per kW-hr. While the couple has lowered their electric use from 190 to $100 \mathrm{~kW}$-hrs per month (a $47 \%$ drop) their electric bill goes from $\$ 21.88$ to $\$ 16.25 /$ month only a $26 \%$ drop. This reduced rate of fiscal return on energy efficiency gains discourages energy efficient practices and the use of more energy efficient technologies. Western Pennsylvania is not an enigma; it was chosen to be demonstrative. The efficiency penalty is directly proportional to the customer charge. The efficiency penalty varies widely from state to state based on the rate structure and customer charge present in the different states as can be seen by Table I.

The customer charge has been increasing on a state by state basis with no national consensus or guidelines. In order to determine the extent of these increases a survey of utility rate tariffs in all 50 states was performed and summarized in Table 1. Table I shows by state: population (U.S. Census Bureau, 2006), average household size (U.S. Census Bureau, 2005), average number of households, a representative electric utility in each state, the monthly customer charge, the aggregate customer charges 
This is a final draft of the published article: J. M. Pearce and Paul J. Harris, "Reducing greenhouse gas emissions by inducing energy conservation and distributed generation from elimination of electric utility customer charges", Energy Policy, 35, pp. 6514-6525, 2007.

per month per state, and the source of the rate information. The average customer charge, $\mathrm{C}_{\mathrm{ave}}$, was found to be $\$ 6.62 /$ month from:

$$
C_{a v e}=\frac{\sum_{s=1}^{50}\left(c_{s} \cdot \frac{p_{s}}{h_{s}}\right)}{\sum_{s=1}^{50} \frac{p_{s}}{h_{s}}}
$$

where $c_{s}$ is the customer charge in a given state, $p_{s}$ is the population of that state and $h_{s}$ is the average household size in that state. Based on this initial survey of electric rates, nationally electric users are paying over $\$ 760$ million/month in customer charges or over $\$ 9$ billion/year. Future work to identify the rates for every utility operating in every state is necessary and expected soon (Edison Electric Institute, 2007), but the numbers from this preliminary survey are enough to lay out the general policy framework for customer charges and draw initial conclusions. As can be seen in Table I, the customer charge varies considerably from state to state, where the lowest charge of $\$ 2.51 /$ month was found in New Jersey and the largest, at $\$ 25 /$ month, was in Utah.

\section{Folding Fixed Costs into Electrical Rates}

In order to implement a new utility rate that contains no customer charges while ensuring that electricity providers make the same revenue as under current regulations, the total money going to the utilities should remain the same for a given aggregate electricity use. The electric rate will have to be increased and this new rate will be called the "efficient rate", $\mathrm{r}_{\mathrm{e}}[\$ / \mathrm{kW}-\mathrm{hr}]$, given by:

$$
r_{e}=\frac{\left(r_{s} \times E_{a v e}+C_{a v e}\right)}{E_{a v e}}
$$

Where $r_{s}$ is the current average standard rate $[\$ / k W-h r], C_{\text {ave }}$ is the current average customer charge determined from Table I and equation (1), and $\mathrm{E}_{\text {ave }}$ is the average energy consumed [kW-hrs] for an individual household/consumer. The average cost of electricity in U.S. in 2006, $\mathrm{r}_{\mathrm{s}}$, was $\$ 0.1047 / \mathrm{kW}-\mathrm{hr}$ (Energy Information Administration, 2007) and the average annual electricity use per household is 10,654 kW-hrs/year (Energy Information Administration, 2005). The average of the customer charges is $\$ 6.62 /$ month having been weighted by the ratio of the number of households in the state to the total number of households in the U.S. via equation (1). The customer charge represents on average about $7 \%$ of the average electric bill, although it ranges from $\sim 3 \%$ to $27 \%$, in New Jersey and Utah respectively. The impact of the customer charge as seen by averages can be misleading because, as will be shown below, for energy efficient users the percentages can be substantially higher.

The average household customer uses $887 \mathrm{~kW}$-hrs/month and at 10.47 cents per $\mathrm{kW}$-hr pays $\$ 92.96$ per month in demand and $\$ 99.58$ per month in total. If the average electric rate is increased by $7.12 \%$ to eliminate the customer charge the average customer still pays $\$ 99.58 /$ month so the rate change is revenue neutral. However, now the average electric rate is $r_{e}=\$ 0.1123 / \mathrm{kW}-\mathrm{hr}$ an increase of $7.5 / 10^{\text {th }} \mathrm{s}$ of a cent per $\mathrm{kW}$-hr. For a more energy efficient customer using only $300 \mathrm{kWh} / \mathrm{month}$ (or about $1 / 3$ of the 
This is a final draft of the published article: J. M. Pearce and Paul J. Harris, "Reducing greenhouse gas emissions by inducing energy conservation and distributed generation from elimination of electric utility customer charges", Energy Policy, 35, pp. 6514-6525, 2007.

average), the monthly bill under the status quo rate structure is $\$ 38.03$ and, under the new rates, is $\$ 33.69$ (decrease of about $13 \%$ ), even though there is no change in usage. If the same family deployed a number of energy saving devices, they could cut their use to $100 \mathrm{~kW}$-hrs/month. Thus, they would decrease their electricity use by $1 / 3$. In the status quo case, their bill would drop from $\$ 38.03$ to $\$ 17.09$ (a drop of 55\%) while with the new rates see a bill of $\$ 33.69 /$ month shrink to $\$ 11.23$ (a decrease of $67 \%$ ). Overall, the energy efficient users would pay $34 \%$ less under the new rates. Thus the less electricity a person uses under the new rate structure using $\mathrm{r}_{\mathrm{e}}$, the greater their incentive to conserve as compared to the standard rate structure.

\section{Potential Greenhouse Gas Emission Reductions}

Growth of renewable energy use will drive down GHG emissions, but it seems clear that increased efficiency and overall decreased use of energy have a potential larger effect on climate stability (Kutscher, 2007). The use of $r_{e}$ to increase the avoidable cost of electricity while eliminating the unavoidable cost of electricity will reduce GHG emissions by leveraging the demand response to encourage efficiency, distributed generation, and less carbon-intensive fuels.

In our current society, price increases generally provide a signal to customers to reduce the amount they consume. The price must of course be avoidable if it is to have this effect. By contrast, lower prices or non-avoidable costs may encourage some customers to consume more than they would have at higher prices. Price changes thus play an important economic function by encouraging customers to respond to changing market conditions (FERC, 2006a). In the electric power industry, consumer's price responsiveness is often referred to as "demand response" to "price elasticity". A price elasticity provides a normalized measure of the intensity of customers' load changes in response to price circumstances, especially for time-varying rates or demand response programs that induce load modifications directly in response to price changes such as the TOU detailed in section 1.2. Demand response is defined as the percentage change in usage for a one-percent change in price, and takes on values of zero and above, in absolute terms (DOE, 2006). For example, if a customer's price elasticity is 0.15 , then a doubling (100\% change) of price results in a 15\% reduction in electricity usage, other things equal. Here we are using the definition for "own-price elasticity", where usage goes down as price goes up. King and Chatterjee (2003) reviewed price elasticity estimates from 36 studies of residential and small commercial customers published between 1980 and 2003. They report an average own-price elasticity in the short run of -0.28 among this group of studies, with studies ranging between -0.23 and -0.34 with $95 \%$ confidence. In the long run they obtained an own-price elasticity of -0.9 with a range of -0.6 to -1.2 with $80 \%$ confidence. So, in this case, we have a $7.12 \%$ increase in the electric rate from folding the customer charge into the per $\mathrm{kW}$-hr rate would be expected to result in a $6.4 \%$ reduction (range $4.3 \%$ to 8.5\%) in overall electricity usage. Electricity consumption by 107 million U.S. households in 2001 totaled 1,140 billion $\mathrm{kW}$-hrs (EIA, 2005). A decrease of $6.4 \%$ would conserve 73 billion $\mathrm{kW}$-hrs (range 49 to 97 billion $\mathrm{kW}$-hrs). The average family using 10,654kW-hrs/year and paying $\$ 1,190 /$ year would see a savings of $\$ 76$ and the regulation change would save the entire U.S. residential sector over $\$ 8$ billion each year. The elimination of customer charges is thus in the best interest of the public on strictly financial grounds. 
This is a final draft of the published article: J. M. Pearce and Paul J. Harris, "Reducing greenhouse gas emissions by inducing energy conservation and distributed generation from elimination of electric utility customer charges", Energy Policy, 35, pp. 6514-6525, 2007.

On average with the U.S. current energy mix, 1.341 pounds of carbon dioxide $\left(\mathrm{CO}_{2}\right)$ are released into the atmosphere for each $\mathrm{kW}-\mathrm{hr}$ produced (DOE and EPA, 2000). This change in electrical rate structure would thus be expected to result in $\mathrm{CO}_{2}$ emission reduction of 97.839 billion pounds or 44.3 million metric tons. This is equivalent to removing over 9.6 million cars from the road assuming 11,400 miles traveled per year (EIA, 2006a) at 22.1 m.p.g (TRB, 2006) and 19.564 pounds of $\mathrm{CO}_{2}$ per gallon of gasoline (EIA, 2006c).

These estimates, although enormous, can be viewed as fairly conservative because the proposed change in electrical rates will reduce GHG emissions by not only encouraging more energy conservation in behaviors/curtailment (e.g. turning off lights, unplugging phantom loads that make up 10\% of current electricity use, or putting computers into sleep mode), but also i) increasing ROI for energy efficiency projects, ii) improving distributed generation and combined heat and power economics, and iii) moving consumers towards less carbon intensive energy sources.

\subsection{Effect on Return on Investment for Energy Efficiency Projects}

Energy efficiency retrofits of both industry and households can provide surprisingly high returns on investment (ROI) (Lovins, et al., 1999; Pearce and Miller, 2006). However, consumers use very high discount rates and thus demand relatively high ROIs when energy efficiency is concerned. As long as the product is purchased on credit, however, and the ROI is greater than the interest rate, then the person pays less money at all times. In fact, because poor people tend to use higher discount rates (require short paybacks), they can benefit more than any other group from eliminating the customer charge. In order to obtain these high ROIs, any increase in avoidable electric rates is useful. The increase of $7.12 \%$ that we determined from Section 3 has a profound effect on the ROI calculated for energy efficiency projects. In order to calculate the ROI for an energy efficiency or distributed generation project the following formula can be utilized (Young, 1993):

$$
\frac{P}{S}=\frac{1-e^{-R T}}{R}
$$

where $\mathrm{P}$ is the difference in principal investment between the efficient device and the standard device the purchase price including installation costs, $\mathrm{S}$ is the value of the energy savings per year, $\mathrm{R}$ is the rate of interest in percent, and $\mathrm{T}$ is the time of life of the energy efficiency device. Thus, the ratio $\mathrm{P} / \mathrm{S}$ is the payback time of the energy efficiency project. The annual savings (S) should take into account the net cost savings in energy, power, water, maintenance, etc. in a year. A simple graphical method has been developed to utilize this equation to compare ROIs from an energy efficiency project to a standard interest rate (Pearce and Uhl, 2003). This same method can be used to see the effect increasing the electric rates by shifting the customer charge into the rate following equation (2).

With the inclusion of a customer charge in current rates, large institutions can effectively obtain a higher ROI on energy efficiency improvements. For example, this perverse incentive explains in part why most major hotel chains have already retrofitted antiquated incandescent lamps with compact fluorescent light (CFL) bulbs, while most small energy consumers have not (e.g. home owners, small business owners, 
This is a final draft of the published article: J. M. Pearce and Paul J. Harris, "Reducing greenhouse gas emissions by inducing energy conservation and distributed generation from elimination of electric utility customer charges", Energy Policy, 35, pp. 6514-6525, 2007.

and most ironically those who need to save small amounts of money the most --- low income families). There is an opportunity to significantly reduce operating costs associated with electricity use by retrofitting existing incandescent lighting with more energy efficient CFLs. CFL bulbs use one quarter the energy to produce the same amount of light (and thus produce one quarter of the pollution and greenhouse gases), fit in the average light socket, last longer, and cost less over their lifecycle than incandescent bulbs. Normally a high ROI can be obtained while reducing greenhouse gas emissions by retrofitting incandescent bulbs with CFLs. Despite widespread availability and ease of implementation, however, CFLs are seldom used in the U.S. (EIA, 1996). Even the most successful publicity campaigns targeted at small businesses and homeowners, generally have success rates 69\% or less (Pearce and Russill, 2005). Often the reason given for non-implementation involves initial investment favoring traditional investments with far lower returns and far greater risk (Pearce and Russil, 2005).

To illustrate the importance of instituting $r_{e}$, consider the effects of an increase in $\$ / k W$-hr due to elimination of the customer charge in New Hampshire from Table I ( $c=\$ 20 /$ month) has on CFL retrofits for different times of use. By rearranging equation (1), the difference in electric rates, $r_{e}-r_{s}$, can be found to be simply c/(average $\mathrm{kW}$-hrs) used or for the $887 \mathrm{~kW}$-hrs it is 2.25 cents per $\mathrm{kW}$-hr. The effect of this seemingly small difference in cost per kW-hr is shown in Figure 2. In Figure 2 avoidable electric rates of 2, 4, 6, 8, 10,12,14, 16 cents per kW-hr for time of use per day of $0.5,1,2,4,6,8,12$, and 24 hours are shown as symbols. The curved lines represent the rate of return for a given investment derived from equation (3). The straight lines connecting the symbols allow one to determine the rate of return at a given $\$ / \mathrm{kW}$-hr basis for any electricity consumption. The lifetime is found by dividing the life of the lamp by the number of hours it is used per year. The increase in the electric rate can have a large effect on the ROI. For example, for the case of the light being used 2 hours per day (lifetime of 11 years) an increase in 2 cents per kW-hr in the least expensive rate (black diamonds to downward pointing open triangles) causes an increase in the ROI from $~ 50 \%$ to $70 \%$ - an increase of $20 \%$ !

As can be seen in Figure 2, in all the cases from the least expensive electricity and low use (1/2 hour per day) to the most expensive electricity using the light 24 hours a day (e.g. safety lighting without conservation controls) the rate of return to retrofit with CFLs is better than, or very competitive with, any standard investment. Not all energy efficient improvements offer such competitive returns so the difference the additional avoidable cost of electricity can be the determining factor for the deployment of energy efficiency projects.

\subsection{Effect on Distributed Generation Economics}

Distributed generation (DG) (also called "Distributed Energy" or "Onsite Generation") allows energy consumers to generate heat and electricity for their own needs on site. DG technologies include: wind turbines, solar photovoltaic cells, fuel cells, microturbines, stirling engines, combustion turbines, and reciprocating engines. DG systems with combined heat and power (CHP) systems can be very efficient. For example, an off-the-shelf microturbine system (Capstone, 2005), which runs on clean natural gas, is $80 \%$ efficient compared to 33\% efficiency for conventional coal fired power plants. These high efficiencies can be obtained because the 'waste' heat from the process to generate electricity is put to 
This is a final draft of the published article: J. M. Pearce and Paul J. Harris, "Reducing greenhouse gas emissions by inducing energy conservation and distributed generation from elimination of electric utility customer charges", Energy Policy, 35, pp. 6514-6525, 2007.

use offsetting energy that would be needed to provide space heating, water heating, or even cooling in the case of absorption chillers. This is unlike the circumstances in conventional power plants where the waste heat actually is wasted, generally being vented to atmosphere.

DG and CHP systems offer several benefits for the public. First, if DG systems are used during peak electrical times, the expansion rate of the centralized grid power system is slowed and additional fossilfuel plants are prevented or pushed into the future. The high efficiencies of CHP and renewable nature of many DG, thus offer both reduced costs and significant reductions of $\mathrm{CO}_{2}$ emissions (Strachan and Farrell, 2006). Some of the reduced costs come from reducing the investment necessary for transport and distribution infrastructures and the postponement of investment decisions on large centralized units (Hoff, 1996; Hoff, et al., 1996; Koeppel, 2003). In sufficient numbers, interconnected DG and CHP systems enhances reliability and security of the grid in the face of natural disasters, war and terrorism; reduced need for transmission and distribution upgrades; and easier plant site determination (Bayless, 1994; Casten and Casten 2001; Zerrif, et al., 2002). Simply put, the more generators on the grid the greater its reliability. Thus the most reliable grid of the future will be one in which every consumer is also a producer, whether it be from a CHP furnace, photovoltaic roof, or plug-in hybrid car. Despite these advantages, CHP and other DG systems are currently not very widespread in the U.S., particularly those on the residential scale. DG and CHP can, however, be far more widespread. For example, in Denmark, the distributed share in the gross electricity production increased from 1\% in 1980 to $35 \%$ in 2001 using 24\% decentralized CHP and 11\% wind turbines (Danish Energy Authority, 2004). So in summary, when CHP systems are deployed the entire electric grid system efficiency is increased, emissions are cut drastically, the grid becomes more reliable and utility customers can save significant energy costs. Clearly, it is in the best interest of the American public to support policies that encourage these technologies to be far more widespread.

CHP systems can be thought of as synonymous with energy efficiency projects and treated similarly as those examples in section 4.1. For an initial investment, a decision maker earns a return in primary energy savings and money. Currently, most CHP systems are primarily found in industry, government or in university cogeneration facilities, although new technologies such as Climate Energy's micro-CHP system are scaled for use in the home. By increasing the amount of avoidable costs for the use of CHP systems, the deployment rates could increase substantially. For example, Hadley, et al. performed a payback analysis for CHP installations in government building. Economic paybacks were 4.3 years in hospital and industrial settings, 5.5 years for prisons, 8.2 years in research and development facilities, 9.3 years in offices and services buildings, and 11.9 years in schools (Hadley, et al., 2002). Some of these facilities thus fall on or near decision rules of thumb of 5 and 10 year paybacks for energy service company contracts (Pearce and Miller, 2006). Elimination of fixed rates such as customer charges increase the advantage of customer-side distributed generation by decreasing the payback period and thus boosting the ROI into regions that either ESCOs or users themselves can finance profitably. Again, because the customer charge is not avoidable, it effectively becomes a sunk cost and actively prevents such CHP systems from being deployed by electricity customers. 
This is a final draft of the published article: J. M. Pearce and Paul J. Harris, "Reducing greenhouse gas emissions by inducing energy conservation and distributed generation from elimination of electric utility customer charges", Energy Policy, 35, pp. 6514-6525, 2007.

The scale and many of the technologies available for customer-side distributed generation have considerable potential. Most homes and businesses could deploy solar photovoltaic arrays on their roofs or replace older furnaces with CHP systems such as the FreeWatt system, which combines a 93\% efficient gas furnace or $95 \%$ efficient gas boiler with a over $85 \%$ efficient (heat and electric) Honda powered natural gas engine-generator module (Climate Energy, 2007). If even 10\% of households in the U.S. installed the $1.2 \mathrm{~kW}$ FreeWatt and $0.6 \mathrm{~kW}$ of solar photovoltaic panels (a very modest installation of a few panels) the grid would have an additional $20 \mathrm{GW}$. These systems, would not of course act as base load, but clearly the potential for DG and CHP is enormous in the residential market. The realization of this potential would be enhanced by the elimination of the customer charge.

\subsection{Customer Charge Effects on Type of Energy Choice}

Not only do increased customer charges directly discourage energy efficiency and distributed generation projects, customer charges also can provide an economic advantage against more efficient and environmentally more favorable choice offered by direct use of natural gas for both residential space heating and water heating. If electric distribution rates are collected in fixed charges such as customer charges, regardless of the type of existing space or water heating for a customer, the electricity rate can be made so low (in some cases "free" for a given amount of energy) that it becomes attractive to switch to electricity over gas. Thus, a rate design heavily fortified with customer charges makes it cheaper for the customer to have the electric utility burn gas or coal relatively inefficiently in a power plant (e.g. $35 \%$ ), transmit (and suffer transmission losses $\sim 6 \%$ (EIA, 2005b)) that electricity over the whole infrastructure, and deliver it to the customer to use for heating rather than have the customer burn gas directly, at greater efficiency ( $>80 \%)$, in an on-site water heater or furnace.

Heating from natural gas furnaces is roughly 2.5 times more efficient than via electric heating. Even if the electricity comes from natural gas turbines, the GHG emissions are roughly $50 \%$ higher than if space and water heating is provided by a distributed network of home furnaces burning the same natural gas. From the view of delivering energy to the population in the most efficient manner possible and to reduce GHG emissions as much as possible - this type of manipulation of energy rates to prevent competition from more efficient technologies is unacceptable.

\section{Limitations to Approach and Future Work}

This paper has shown that any inclusion of distribution costs in a fixed customer charge effectively double charges energy efficient and low-use users. Efficient users are subsidizing 'energy hogs' under the current rate structure found in all U.S. States. In section 2 we quantified the efficiency penalty that is shouldered by the energy efficient and low-use electricity customers because of the customer charge. Section 4 showed that the public is also currently subsidizing both increased external costs (unnecessary $\mathrm{CO}_{2}$ emissions and concomitant climate disruption) and increased economic costs due to disincentives caused by the customer charge for energy efficiency, distributed generation, and rational fuel sources for heating. The preliminary attempts to quantify these costs and externalities presented in this paper should be enhanced by more rigorous studies of each cost individually. In particular, the value of efficiency, DG and CHP, and fuel choices must be determined for their economic benefits in the context of expanding energy use. This factor can be considerable because any measure that reduces the need for 
This is a final draft of the published article: J. M. Pearce and Paul J. Harris, "Reducing greenhouse gas emissions by inducing energy conservation and distributed generation from elimination of electric utility customer charges", Energy Policy, 35, pp. 6514-6525, 2007.

additional construction of transmission and distribution assets will offset on average over $\$ 1,300 / \mathrm{kW}$ (Little, 2000). Thus, the cost of delivered electricity can actually decrease in the long term for all customers due to current forward thinking policy to encourage efficiency, DG, and decarbonized fuel sources. It is clear, however, from the preceding limited information that it is in the public's best interest for the customer charge to be folded into a charge based on energy use. Finally, additional work is needed to quantify the management implications of this proposal in far more detail than can be presented here.

\section{Summary and Conclusions}

In general, PUCs support rate structures that encourage conservation and help consumers reduce their overall bills. However, they are pressed by the utilities to support fixed costs as much as possible for the reasons outlined earlier. Viewed from the electric utility perspective, the elimination of the customer charges may appear to be a subsidy for the energy efficient consumer who would not be paying their share of fixed customer costs. Unfortunately, the external costs generated from the incorrect market signals from the customer charge currently are born by all users. The PUCs must show that any alternative method of structuring rates allows the utility to recover the fixed costs of metering and services that are incurred by all users, whether efficient in their usage or not. The method outlined in this paper gives them the tool to do this, while potentially easing oversight by eliminating large amounts of unnecessary accounting/paperwork and increasing efficiency even further. This paper showed if customer charges are eliminated by increasing in the electric rate there would be a $6.4 \%$ reduction in overall electricity consumption, conserving 73 billion $\mathrm{kW}$-hrs, eliminating 44.3 million metric tons of carbon dioxide, and saving the entire U.S. residential sector over $\$ 8$ billion per year. In this case, it appears that doing what is in the best financial interest of the utilities is not in the best interest of the society as a whole, even including the large energy users.

Currently there is a penalty of increased costs per $\mathrm{kW}-\mathrm{hr}$ for instituting energy efficiency improvements, distributed generation, and improved energy conservation behaviors because of fixed customer charges. For efficient energy consumers, customer charges can represent a considerable percentage of their monthly bills making the effective rate of electricity extremely high. These unavoidable costs actually encourage consumers to waste energy and avoid making efficiency investments. The U.S.'s homeowners and small business owners would benefit considerably if the utilities were required to eliminate fixed customer charges. In this way, small energy users could more easily replicate the energy efficiency improvements being made by industry and academia. If the identical value of the aggregate customer charge is distributed among all customers based on the amount of electricity they use the following occurs: i) the rate will increase (cost per kW-hr) on average for energy consumers while decreasing their total bill because, ii) this increase in the rate will encourage energy efficiency by increasing the rate of return on energy efficiency investments and increasing the economic feedback of conservation behaviors, iii), distributed energy generation is encouraged by aligning the cost of electricity use for consumers more closely to the true cost of our electrical system and thus increasing the efficiency of both the electrical and thermal energy systems, iv) the deficiency of the rate system which rewards large energy consumers and less efficient users of energy by having small energy users 
This is a final draft of the published article: J. M. Pearce and Paul J. Harris, "Reducing greenhouse gas emissions by inducing energy conservation and distributed generation from elimination of electric utility customer charges", Energy Policy, 35, pp. 6514-6525, 2007.

and energy efficient consumers subsidize their use through customer charges will be corrected, v) green house gas emissions will be reduced by combining all these market signals to energy consumers to both reduce energy use, increase energy efficiency and distributed energy, and move towards renewable sources of energy. The utilities would still obtain the same compensation as they do with the current regulation; however, now the costs of energy would be equitably distributed between large and small energy consumers. The additional benefits of an incentive for utility customers to reduce energy use is clear (e.g. less "burned" money which could be used more productively in another sector of the economy, conservation of energy for U.S. national security, environmental protection by reducing emissions if it is assumed that small energy users would respond to the market incentive of greater avoidable costs, etc.).

\section{Acknowledgements}

This work was supported from a grant from National Fuel Gas Distribution Corporation.

\section{References:}

Bayless, C., 1994. Why gas turbines will transform electric utilities. Public Utilities Fortnightly 132 (22), 21-25.

Capstone, 2005. Capstone Introduces the C65 Energy Systems. Capstone Turbine Corp. 330200-001 Rev. A.

Casten, T., Casten, S., 2001. Transforming Electricity. Northeast Midwest Economic Review, Nov/Dec.

Climate Energy, 2007. FreeWatt Combined Heat and Power for the Home. Climate Energy, Medfield, Massachusetts.

Danish Energy Authority, 2004. Energy in Denmark 2003. Danish Energy Authority, Copenhagen.

Department of Energy (DOE), 2006. Benefits of Demand Response in Electricity Markets and Recommendations for Achieving Them: A Report to the United States Congress Pursuant to Section 1252 of the Energy Policy Act of 2005, February 2006 (DOE EPAct Report).

Department of Energy (DOE), Environmental Protection Agency (EPA), 2000. Carbon Dioxide Emissions from the Generation of Electric Power in the United States. DOE and EPA: Washington D.C.

Edison Electric Institute, 2007. Personal communication.

Energy Information Administration (EIA).1996. Residential Lighting: Use and Potential Savings. Office of Energy Markets and End Use. U.S. Department of Energy, Washington: DC. DOE/EIA-0555(96)/2. 
This is a final draft of the published article: J. M. Pearce and Paul J. Harris, "Reducing greenhouse gas emissions by inducing energy conservation and distributed generation from elimination of electric utility customer charges", Energy Policy, 35, pp. 6514-6525, 2007.

Energy Information Administration (EIA), 2005. U.S. Household Electricity Report. Release date: July 14, 2005 Available: http://www.eia.doe.gov/emeu/reps/enduse/er01_us.html

Energy Information Administration (EIA) (2005b) ‘Annual Energy Review 2004’ Energy Information Administration. DOE/EIA-0384.

Energy Information Administration (EIA), 2006a. Transportation Energy Consumption Surveys Energy Used by Vehicles, Chapter 3. Vehicle-Miles Traveled, Available: http://www.eia.doe.gov/emeu/rtecs/chapter3.html

Energy Information Administration (EIA), 2006c. Fuel and Energy Source Codes and Emission Coefficients, Available: http://www.eia.doe.gov/oiaf/1605/factors.html

Energy Information Administration (EIA), 2007. Average Retail Price of Electricity to Ultimate Customers by End-Use Sector, by State, Electric Power Monthly with data for October 2006 Report. Average Cost of electricity (by year, by customer type, total).

Federal Energy Regulatory Commission (FERC), 2006a. United States of America Electric Energy Market Competition Task Force and the Federal Energy Regulatory Commission Notice Requesting Comments on Draft Report to Congress on Competition in the Wholesale and Retail Markets for Electric Energy Docket No. AD05-17-000.

Federal Energy Regulatory Commission (FERC), 2006. FERC Assessment of Demand Response and Advanced Metering Staff Report Docket AD06-2-000, Washington D.C.

Hadley, S.W., Kline, K. L., Livengood, S. E., Van Dyke, J. W., 2002. Analysis of CHP Potential at Federal Sites. ORNL/TM-2001/280.

Hoff, T.E., 1996. Identifying distributed generation and demand side management investment opportunities. The Energy Journal 17 (4), 89-106.

Hoff, T.E., Wenger, H.J., Farmer, B.K., 1996. Distributed generation. An alternative to electric utility investment in system capacity. Energy Policy 24 (2), 137-147.

Intergovernmental Panel on Climate Change (IPCC). 2007a. Climate Change 2007: The Physical Science Basis, Summary for Policymakers Contribution of Working Group I to the Fourth Assessment Report. IPCC Secretariat, Geneva, SWITZERLAND.

The Intergovernmental Panel on Climate Change (IPCC). 2007b. Working Group II Contribution to the Intergovernmental Panel on Climate Change, Fourth Assessment Report, Climate Change 2007: Climate Change Impacts, Adaptation and Vulnerability, IPCC Secretariat, Geneva, SWITZERLAND. 
This is a final draft of the published article: J. M. Pearce and Paul J. Harris, "Reducing greenhouse gas emissions by inducing energy conservation and distributed generation from elimination of electric utility customer charges", Energy Policy, 35, pp. 6514-6525, 2007.

King, C. S., Sanjoy, C., 2003. Predicting California Demand Response, Public Utilities Fortnightly 141(13), 27.

Koeppel, G., 2003. Distributed Generation—Literature Review and Outline of the Swiss Situation. ETH, Zurich.

Kutscher, C.F. (editor) 2007. Tackling Climate Change in the U.S.: Potentail Carbon Emissions Reductions rom Energy Efficiency and Renewable Energy by 2030. American Solar Energy Society.

Little, A. D. 2000. Preliminary Assessment of Battery Energy Storage and Fuel Cell Applications in Building Applications, Final Report to the National Renewable Energy Laboratory.

A. Lovins, H. Lovins, and P. Hawken, 1999. Natural Capitalism - Creating the Next Industrial Revolution, Little Brown and Company, New York.

Marcus, W. B., Coyle, E. P., 1999. Customer Charges in the Restructured World: Historical, Policy, and Technical Issues adapted from a presentation to the National Association of Regulatory Utility Commissioners Energy Resources and Environment Committee, July 20, 1999.

Pearce J. M., Hanlon, J. T., 2007. Energy Conservation from Systematic Tire Pressure Regulation, Energy Policy 35 (4), 2673-77.

Pearce J. M., Miller, L. L., 2006. Energy Service Companies as a Component of a Comprehensive University Sustainability Strategy, Int. J. of Sustainability in Higher Education 7(1), 16-33.

Pearce, J., Russill, C., 2005. Interdisciplinary Environmental Education: Communicating and Applying Energy Efficiency for Sustainability. Applied Environmental Education and Communication 4(1), 6572.

Pearce, J.M., Uhl, C., 2003. Getting It Done: Effective Sustainable Policy Implementation at the University Level, Planning for Higher Education, 31(3), 53-61.

Southern Californian Edison Company, 2000. Application of Southern Californian Edison Company for Post-Transition Rates, A.00-01-009, filed January 7, 2000.

Sterzinger, G.J. 1981. The Customer Charge and Problems of Double Allocation of Costs, Public Utilities Fortnightly, July 2, 1981, pp. 30-32.

Strachan, N., Farrell, A. 2006. Emissions from distributed vs. centralized generation: The importance of system performance. Energy Policy 34, 2677-2689. 
This is a final draft of the published article: J. M. Pearce and Paul J. Harris, "Reducing greenhouse gas emissions by inducing energy conservation and distributed generation from elimination of electric utility customer charges", Energy Policy, 35, pp. 6514-6525, 2007.

Takahashi, K., Baker, S., Kurdgelashvili, L., Byrne, J., Glover, L., 2005. Policy Options to Support Distributed Resources: A Report to Conectiv Power Delivery. Center for Energy and Environmental Policy, University of Delaware.

Taylor, T.N., Schwarz, P.M., 1990. The Long-Run Effects of a Time-of-Use Demand Charge, The RAND Journal of Economics 21(3), 431-445.

Transportation Research Board (TRB). 2006. Tires and Passenger Fuel Economy: informing Consumers, Improving Performance, Transportation Research Board Special Report 286. National Research Council of the National Academy of Sciences, Washington, D.C.

U.S. Census Bureau, 2005. Average Household Size: 2005. Universe: Households. Survey: 2005 American Community Survey, 2005 Puerto Rico Community Survey. Geographic Area: United States and States.

U.S. Census Bureau Population Division, 2006. Table 1: Annual Estimates of the Population for the United States, Regions, and States and for Puerto Rico: April 1, 2000 to July 1, 2006 (NST-EST200601).

U.S. Environmental Protection Agency. 2006. Inventory of U.S. Greenhouse Gas Emissions and Sinks: 1990-2004, U.S. Environmental Protection Agency, Washington, D.C.

Weston, F., Harrington, C., Moskovitz, D., Shirley, W., Cowart, R. 2000. Charging for Distribution Utility Services: Issues in Rate Design. The Regulatory Assistance Project, Montpelier, VT.

D. Young, 1993. Modern Engineering Economy. J. Wiley, New York.

Zerrif., H., Dowlatabadi, H., Strachan, N., 2002. Electricity and conflict: advantages of a distributed system. The Electricity Journal 15 (1), 55-65. 
This is a final draft of the published article: J. M. Pearce and Paul J. Harris, "Reducing greenhouse gas emissions by inducing energy conservation and distributed generation from elimination of electric utility customer charges", Energy Policy, 35, pp. 6514-6525, 2007.

Table I. By state: population, average household size, average number of households, a representative electric utility, customer charge, aggregate customer charges per state, and source for rate information. 
This is a final draft of the published article: J. M. Pearce and Paul J. Harris, "Reducing greenhouse gas emissions by inducing energy conservation and distributed generation from elimination of electric utility customer charges", Energy Policy, 35, pp. 6514-6525, 2007.

\begin{tabular}{|c|c|c|c|c|c|c|c|}
\hline State & Population & \begin{tabular}{|l} 
Average \\
Household \\
Size
\end{tabular} & Households & $\begin{array}{l}\text { Company/Rate Schedule (All } \\
\text { are Residential unless } \\
\text { otherwise noted) }\end{array}$ & $\begin{array}{l}\text { Customer } \\
\text { Charge } \\
\text { (\$/Month) }\end{array}$ & $\begin{array}{l}\text { Customer Charge per State } \\
\text { per Month }\end{array}$ & Source \\
\hline Alabama & $4,599,030$ & 2.48 & $1,854,447.58$ & Southern Company & 8.91 & $16,523,127.94$ & $\begin{array}{l}\text { Alabama Power, 2007. Electric Pricing. Southtern Company. } \\
\text { Available: } h t t p: / / \text { www.alabamapower.com/pricing/pdf/fd.pdf }\end{array}$ \\
\hline Alaska & 670,053 & 2.75 & $243,655.64$ & $\begin{array}{l}\text { Alaska Electric Light and Power } \\
\text { Company }\end{array}$ & $\$ 8.88$ & $2,163,662.05$ & $\begin{array}{l}\text { Alaska Electric Light and Power Company, 2007. Electric } \\
\text { Rates. Available: http://www.aelp.com/Rates/ourrates.htm }\end{array}$ \\
\hline Arizona & $6,166,318$ & 2.65 & $2,326,912.45$ & Salt River Project/Residential & $\$ 10.15$ & $23,618,161.40$ & $\begin{array}{l}\text { Salt River Project Agricultural Improvement and Power District, } \\
\text { 2006. Standard Price Plan for Residential Service. Available: } \\
\text { http://www.srpnet.com/prices/pdff/BasicPlan1106.pdf }\end{array}$ \\
\hline Arkansas & $2,810,872$ & 2.48 & $1,133,416.13$ & Entergy & $\$ \quad 6.94$ & $7,865,907.94$ & $\begin{array}{l}\text { Arkansas Public Service Commission, } 19 \text { December } 1997 . \\
\text { General Purpose Residential Service. Available: } \\
\text { http://wmw.apscservices.info/tariffs/1_elec_1.PDF }\end{array}$ \\
\hline California & $36,457,549$ & 2.92 & $12,485,461.99$ & City of Riverside & $\$ \quad 5.00$ & $62,427,309.93$ & $\begin{array}{l}\text { City of Riverside, California, 2007. U-Rate Program: Time-of-use } \\
\text { Residential Electric Rate. Avavilable: } \\
\text { http.//nww.riversideca.gov/utilities/resi-urate.asp }\end{array}$ \\
\hline Colorado & $4,753,377$ & 2.51 & $1,893,775.70$ & Estes Park/Residential & $\$ \quad 4.00$ & $7,575,102.79$ & $\begin{array}{l}\text { Town of Estes Park, Colorado, 2003. Residential Rates. } \\
\text { Available: } h t t p: / / \text { www.estesnet.com/finance/powerrates.aspx }\end{array}$ \\
\hline Connecticut & $3,504,809$ & 2.56 & $1,369,066.02$ & Groton Utilities & 9.14 & $12,513,263.38$ & $\begin{array}{l}\text { Groton Utilitities, 2002. Electric Rates.Available: } \\
\text { http://www.grotonutilities.com/electric_rates.asp }\end{array}$ \\
\hline Delaware & 853,476 & 2.58 & $330,804.65$ & Delmarva & $\$ 11.32$ & $3,744,708.65$ & \begin{tabular}{|l|} 
Delmarva Power and Light Company, 2006. Delaware \\
Residential Rates. Available: \\
http://mww.delmarva.com/_res/documents/DEresrates9_06.pdf
\end{tabular} \\
\hline Florida & $18,089,888$ & 2.47 & $7,323,841.30$ & $\begin{array}{l}\text { Florida Power and Light } \\
\text { Company }\end{array}$ & 5.17 & $37,864,259.50$ & $\begin{array}{l}\text { Florida Power \& Light Company, } 1 \text { April 2003. Residential Load } \\
\text { Control Pilot Project. Available: } \\
\text { http://mww.fpl.com/rates/pdf/electric tariff section8.pdf }\end{array}$ \\
\hline Georgia & $9,363,941$ & 2.66 & $3,520,278.57$ & Georgia Power & 7.50 & $26,402,089.29$ & $\begin{array}{l}\text { Georgia Power, 2007. Residential Service Schedule: "R-15". } \\
\text { Southern Power Company. Available: } \\
\text { http://mww.georgiapower.com/pricing/gpc-pdf/R-15.pdf }\end{array}$ \\
\hline Hawaii & $1,285,498$ & 2.88 & $446,353.47$ & HECO/Residential & 7.00 & $3,124,474.31$ & $\begin{array}{l}\text { Hawaiian Electric Company, Inc., 2005. Average Electric Rates } \\
\text { for Hawaiian Electric Co., Maui Electric Co. and Hawaii Electric } \\
\text { Light Co. Available: } \\
\text { http://www.heco.com/portal/site/heco/menuitem.205167079283 } \\
14340 \text { buc0610c510b1ca/?vgnextoid=a0baf2b154da9010VgnVC } \\
\text { M10000053011bacRCRD\&vgnextfmt=default }\end{array}$ \\
\hline Idaho & $1,466,465$ & 2.62 & $559,719.47$ & Idaho Power/Residential & $\$ \quad 4.00$ & $2,238,877.86$ & $\begin{array}{l}\text { Idaho Power Company, } 31 \text { May 2006. Schedule } 1 \text { Residential } \\
\text { Service. Available: } \\
\text { http://www.idahopower.com/aboutus/regulatoryinfo/tariffPdf.asp } \\
\text { ?id=156\&.pdf }\end{array}$ \\
\hline |llinois & $12,831,970$ & 2.65 & $4,842,252.83$ & Mid-American Energy & 5.12 & $24,792,334.49$ & $\begin{array}{l}\text { MidAmerican Energy, } 18 \text { December 2006. Rate No. } 10 \\
\text { Residence Electric Service. MidAmerican Energy Company. } \\
\text { Docket No. 06-0690. Available: } \\
\text { http://www.midamericanenergy.com/pdf/rates/elecrates/lielectri } \\
\text { c/5-5.10.pdf }\end{array}$ \\
\hline Indiana & $6,313,520$ & 2.49 & $2,535,550.20$ & Lebanon Utilities/Residential & $\$ \quad 5.00$ & $12,677,751.00$ & $\begin{array}{l}\text { The Lebanon Utilities, 2005. Electric Rates. Available: } \\
\text { http://www.lebanon-utilities.com/e_rates.html }\end{array}$ \\
\hline Lowa & $2,982,085$ & 2.38 & $1,252,976.89$ & Mid-American Energy & 6.00 & $7,517,861.34$ & $\begin{array}{l}\text { MidAmerican Energy, 2007. Electric Tariffs: lowa. MidAmerican } \\
\text { Energy Company. Available: } \\
\text { http.//www.midamericanenergy.com/html/rates } 1 \mathrm{~b} 3 \text {.asp }\end{array}$ \\
\hline
\end{tabular}


This is a final draft of the published article: J. M. Pearce and Paul J. Harris, "Reducing greenhouse gas emissions by inducing energy conservation and distributed generation from elimination of electric utility customer charges", Energy Policy, 35, pp. 6514-6525, 2007.

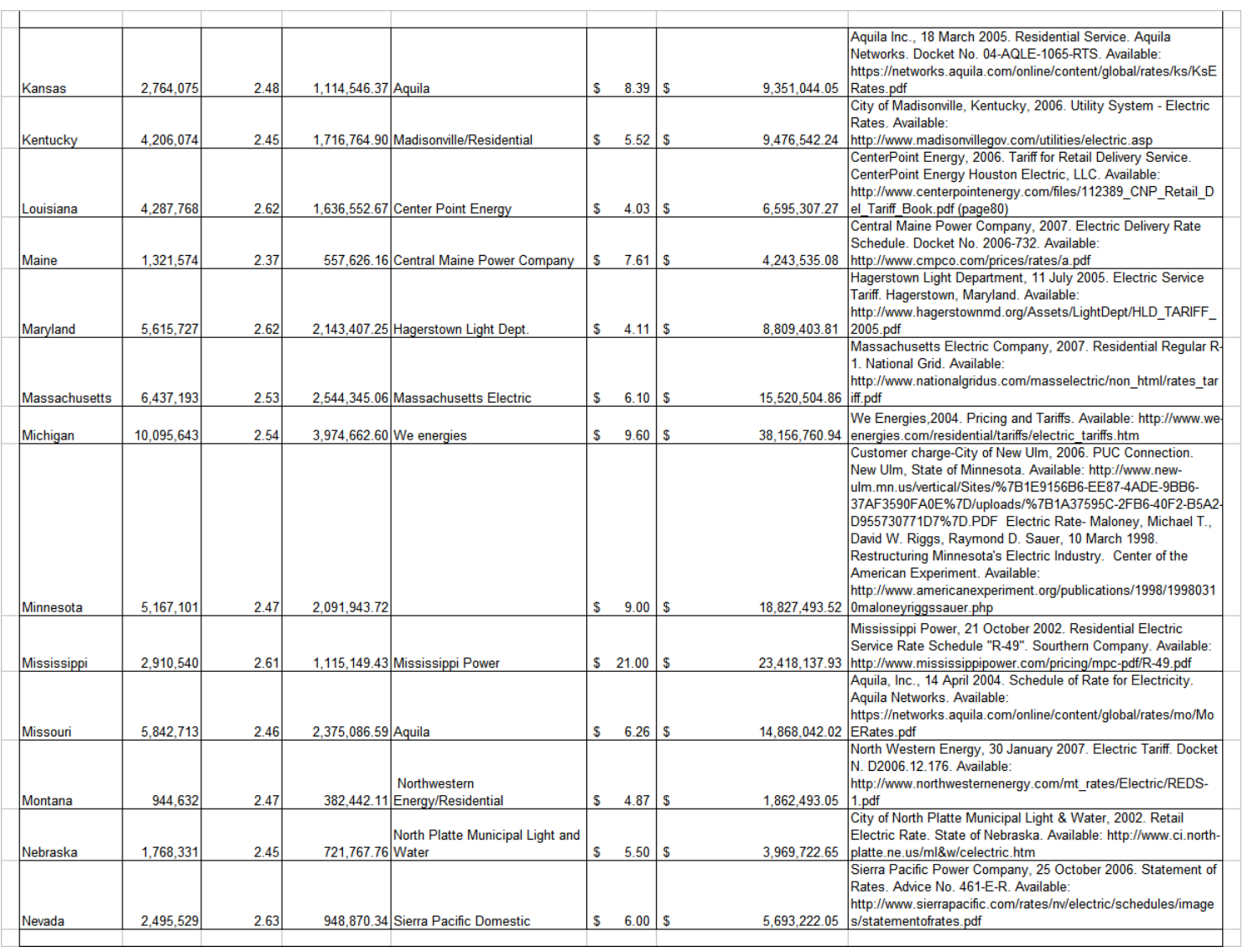


This is a final draft of the published article: J. M. Pearce and Paul J. Harris, "Reducing greenhouse gas emissions by inducing energy conservation and distributed generation from elimination of electric utility customer charges", Energy Policy, 35, pp. 6514-6525, 2007.
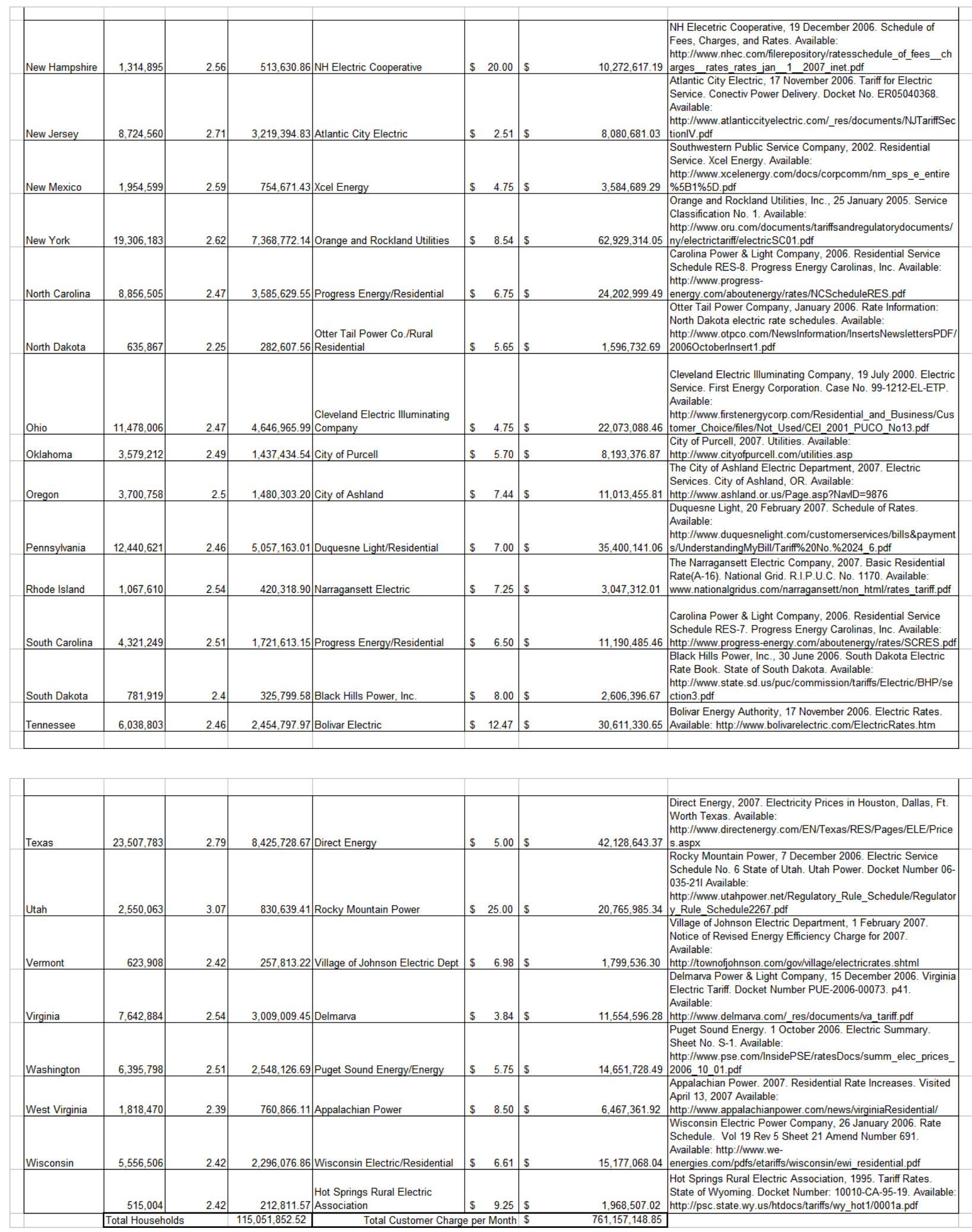
This is a final draft of the published article: J. M. Pearce and Paul J. Harris, "Reducing greenhouse gas emissions by inducing energy conservation and distributed generation from elimination of electric utility customer charges", Energy Policy, 35, pp. 6514-6525, 2007. 
This is a final draft of the published article: J. M. Pearce and Paul J. Harris, "Reducing greenhouse gas emissions by inducing energy conservation and distributed generation from elimination of electric utility customer charges", Energy Policy, 35, pp. 6514-6525, 2007.

Fig. 1

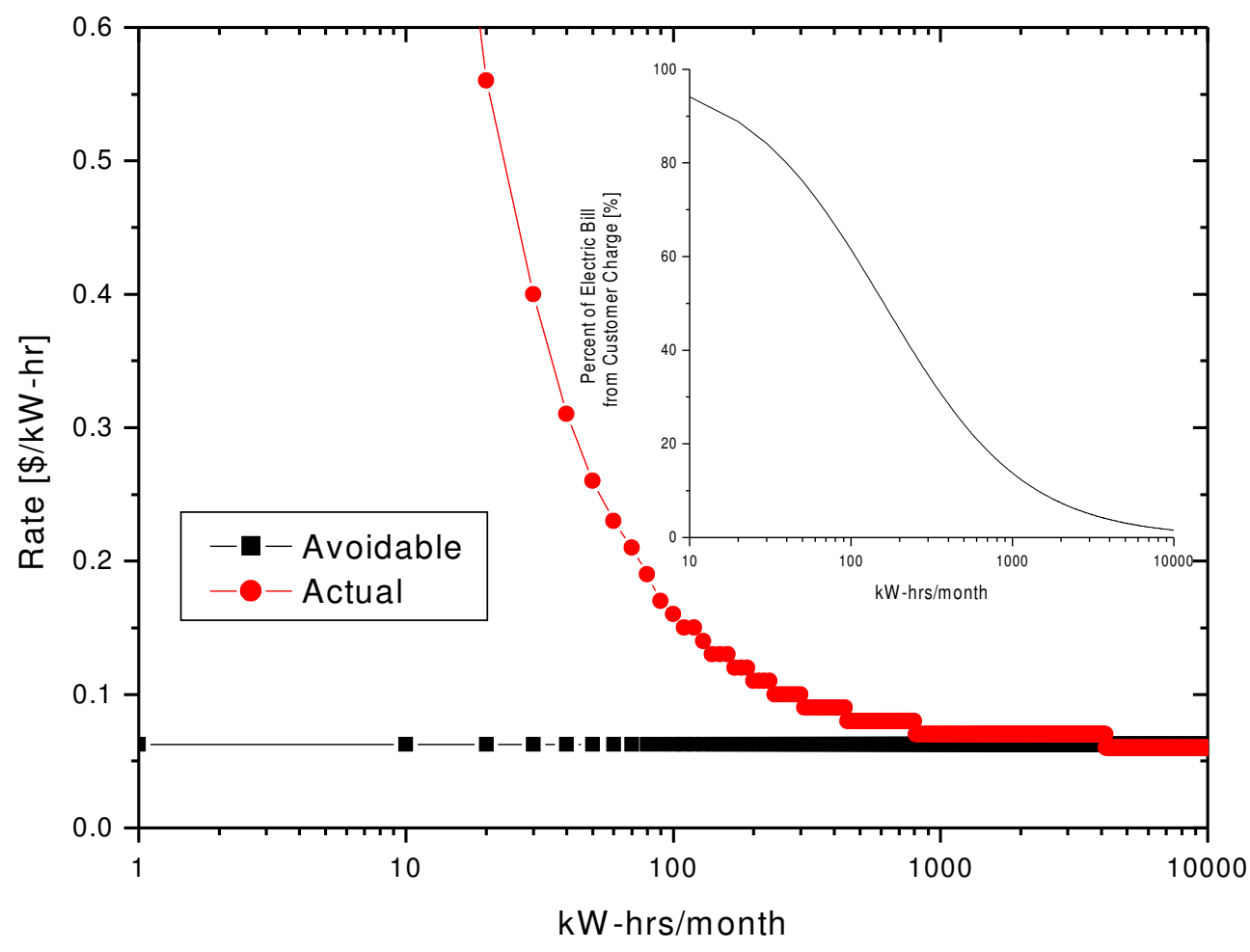

Figure 1. Actual Total Rate and Avoidable Rate $[\$ / \mathrm{kW}-\mathrm{hr}]$ as a function of Electricity Consumption for Allegheny Power customers. The inset shows the percent of the total electric bill due to the consumer charge as a function of $\mathrm{kW}-\mathrm{hrs} / \mathrm{month}$. 
This is a final draft of the published article: J. M. Pearce and Paul J. Harris, "Reducing greenhouse gas emissions by inducing energy conservation and distributed generation from elimination of electric utility customer charges", Energy Policy, 35, pp. 6514-6525, 2007.

Fig. 2

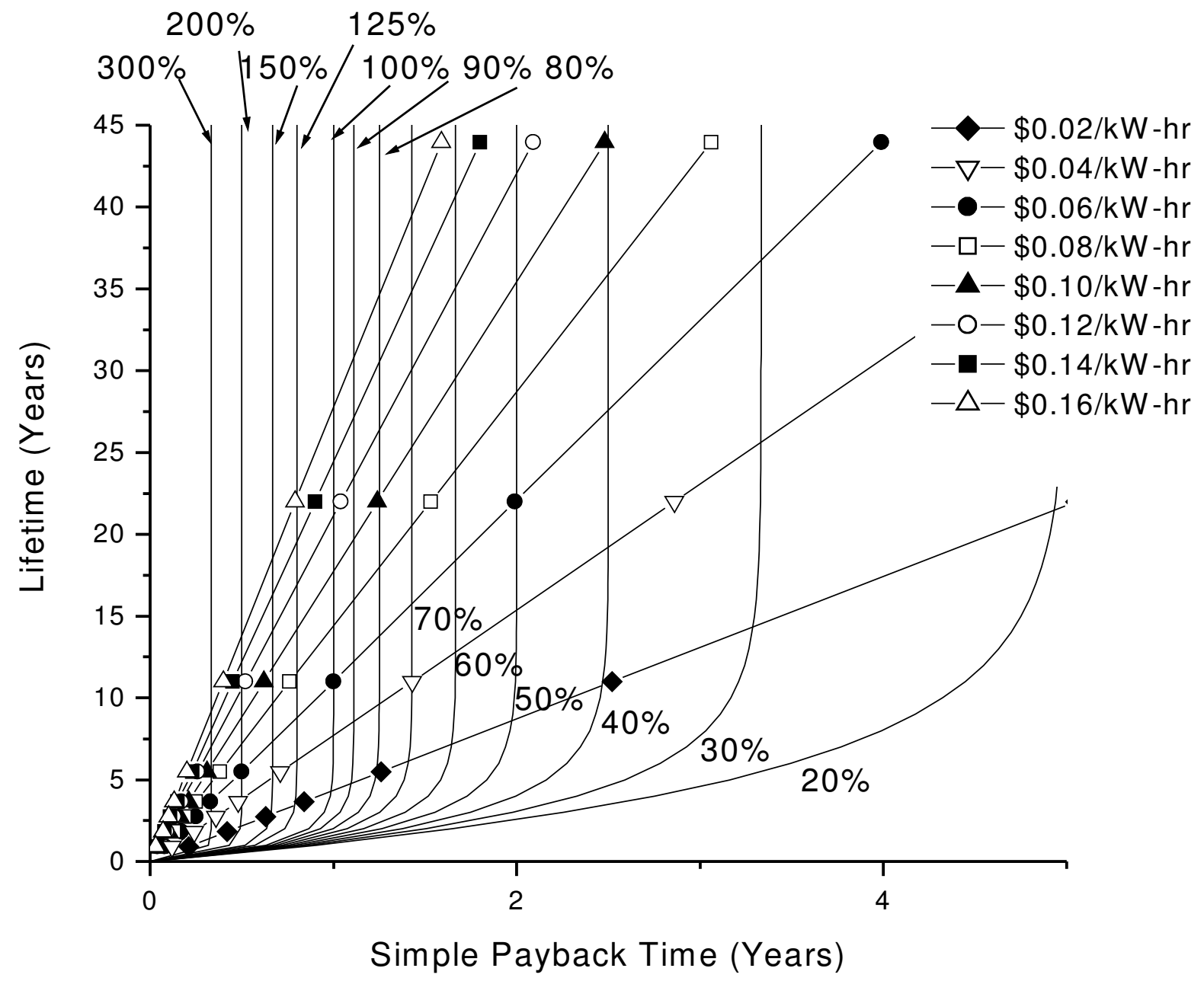

Figure 2. Simple payback time (P/S) vs lifetime (T) for CFL retrofits for varying electrical rates and time of use per day. 